\title{
Limitations of Market Reforms in a Neo-Liberal World Economy
}

\author{
ADEWOLE MUSILIU ADEOLU \\ Department of Economics, School of Management Technology, \\ Federal University of Technology, Akure Ondo State Nigeria
}

\begin{abstract}
A number of sequential events spanning the last fifty years has given proponents of capitalism, advocating minimal state involvement in the economy, decisive victory, not only over socialism but over heavy government engagement in the economy The main contention of this piece is to prove that the failures of government and public sector did not necessarily make a strong case for the market reforms which was being promoted in SSA and other transition economies. In fact what is often distorted or misrepresented as the successes of unfettered markets are on closer examination evidences in favour of strong government and developmental states which have been able to overcome the so-called 'Weingast Paradox. Drawing from the historical experience and the successes of a few countries in Far East Asia in addition to the successes of China and India, we make strong case for government-driven economic development after policy-makers have been subjected to the constraints of political and economic institutions.
\end{abstract}

DOI: $10.7176 / \mathrm{DCS} / 9-5-03$

Publication date:May $31^{\text {st }} 2019$

\section{Introduction}

A number of sequential events spanning the last fifty years has given proponents of capitalism with minimal state involvement in the economy decisive victory, not only over socialism but over heavy government engagement in the economy. The phenomenal economic growth experienced by South Korea after they broke away from North Korea and similar experience of great economic leap of West Germany over its Eastern counterparts has given great impetus to their pro-market ideology. The demise of socialism in Eastern Europe and several other countries in the world after the disintegration of former U.S.S.R represents significant milestone in the march towards a unipolar world of capitalism, where governments are only marginally important in the development process.

If all these are combined with the evident failure of government-directed development in Sub-Saharan Africa, one should not need any serious convincing that market-driven process is all that is required to achieve to rapid economic growth and development. In order to convince us of the futility of state-driven development process, scholars gave several appellations to Africa states, particularly the poorly performing ones in SubSaharan Africa. The appellations include the 'prebendal state', failed state, fragile state, personal-rule state, clientelist state, neopatrimonial state, predatory state, crony state, overextended state, kleptocratic state, inverted state, lame leviathan, etc (Mkandiwire 2001)

While these numerous appellations may be an over-reaction, or even exaggeration of the extent of development crisis in Sub-Saharan Africa, there are quite a number of disturbing trends in African governance landscape that gave little prospect for growth and development in the future. Artadi and Sala-i-Martin (2003) mentioned a number of the features of Sub-Saharan Africa (SSA) that actually made the $20^{\text {th }}$ century an economic tragedy for that part of the continent. According to them, SSA per capita GDP is far below that of the other continents and countries in the Northern part of Africa. From a peak per capita in 1974, which by all standards was low, nearly 30 years after, per capita GDP is 200 dollars smaller. Kayode (2004) produced a table showing the contemporaries of Nigeria in the 60s. Removing Nigeria (our per capita GDP is \$258) from the list, Singapore is the country with the highest per capita $(\$ 30,000)$ and country with the least per capita income is Namibia $(\$ 2,059)$. While Namibia is nearly eight times richer than Nigeria, Singapore is more than 116 times richer. Thus while growth decline in SSA countries, growth soared elsewhere, particularly in East Asia.

Within this period income distributions worsen. Not only was upward social mobility impeded but the conditions of the poorest segment actually grew worse. However, the richest segment of the society was relatively unaffected by the slide in the economic fortunes of SSA. For the Africa continent the Gini coefficient, which measures the extent of income inequality, increased from 0.57 in 1970 to 0.63 in the year 2000. For SSA during the 1970-2000 period, the Gini coefficient rose from 0.58 to 0.65 . On several other counts, such poverty rates, cost of public investment, investment rate measured as the ratio of investment to GDP, human capital formation, investment in health, institutional capacity and many others, SSA fared worse when compared to other continents.

Krueger (1990) also mentioned government failures of omission and commission. Government indeed overreached itself by running high cost public sector firms producing essentially private goods. Government also established monopoly marketing boards for the purchase of agricultural produce for export, with negative consequences for farmers' welfare and overall development. Added to these are wasteful and inefficient 
government investment programmes, mounting budget deficits due to inefficient government enterprises, excessive investment programmes, politically motivated distortions in the economy, collapse of public infrastructure and all the attendant macroeconomic instability.

Because of the pervasive failures of government in development, one of strongly advocated measures was and still is privatization. The privatization agenda would ensure a minimalist state involvement in the economy and would make economic development essentially private-sector driven. Privatization will drive private incentives for profits which will encourage efficiency, innovation and better quality service. It will provide contracting opportunities for goods with high degree of publicness which can paid for by government but provided by the private sector ( Shleifer 1998). For the pro-privatization group to make a strong case for their proposition, numerous studies were done that showed that public sector firms often under-performed relative to their private-sector counterparts (see World Bank 1995 for review and acknowledgement of these studies).

While it is obvious that both the government and markets work imperfectly in developing countries, Western scholars and of course international finance institutions such as World Bank and IMF believed the sure way out of the development quagmire is first the creation of free markets unfettered by inappropriate government interventions. Much later, agenda for the reforms of governance and public sector service was put on the table.

The main contention of this piece is to prove that the failures of government and public sector did not necessarily make a strong case for the market reforms which was being promoted in SSA and other transition economies. In fact what is often distorted or misrepresented as the successes of unfettered markets are on closer examination evidences in favour of strong government and developmental states which have been able to overcome the so-called 'Weingast Paradox'.

The rest of this paper is organised as follows. The second section provides evidences to show the failures of market reforms carried out with the intention of retrenching public sector activities or minimizing state involvement in the running of the economy. In the third section we make a case for the evolution of strong political institutions to minimize the many instances of government failures, to promote developmental state and governance. In section four, we argue that the certain route to creating a developmental state and public-private driven development lies in institutionalization of mechanism for selecting quality political leaders into public office. The last section summaries our argument and draw necessary conclusions.

\section{Limits of Market Reforms}

The initial push for market reforms in SSA and other transition economies as a fundamental means of resource allocation was done in flagrant disregard of the political context of free market system. In other words, introduction of free market was seen, and is still seen to some extent, as the all-in-all panacea to the fundamental crisis of underdevelopment in the countries where market reform policy has been vigorously advocated. The history of capitalism itself did not provide any guide to scholars and international finance institutions as to the need to put in place strong institutional mechanism that would make to make free market work. In the words of Shleifer and Vishny (1998)

"Privatization then offers an enormous political benefit for the creation of institutions supporting private property because it creates the very private owners who then begin lobbying the government...to create market-supporting institutions... [Such] institutions would follow private property rather than the other way round." (pp. 10-11)

The expectations of these western scholars, of course, were not realised. Mass and speedy privatization did not prompt the economic institutions that are required to achieve widespread prosperity. The central argument of this paper still remains that fundamental political and economic institutional changes are important pre-requisite for the success or otherwise of economic reforms.

From North and Weingast (1989) classic study, we at least have an idea of how political institutions could offer support to the evolution of the market system. The essential thrust of their work was to show that the evolution of strong institutions which curtailed the arbitrary powers of the monarchy secured the credible commitments required to encourage private investment and reassure investors that money borrowed by the monarchy would be returned. When the monarchy retained the discretionary powers to make state policies and reverse it when it in their interest to do so, private investors never felt secured to make growth-enhancing investments. When monarchy could confiscate property or repudiate debts, growth was slow and stagnant, and government was frequently running deficits. Mounting deficits was due to lenders increasing unwillingness to grant substantial loans to the English monarchy.

If history is any guide, neither a weak state nor a minimalist government can lead to the establishment of a strong and free market system. In fact, both weak state and minimalist government cannot guarantee strong and vibrant market system. Strong state and government are therefore required for the institutionalization of a

\footnotetext{
${ }^{1}$ The government that is strong enough to promote rapid development is equally strong enough to impede it.
} 
process that would overcome the Weingast paradox and make governance less dependent on persons. They ensure that the benefits of governance are not restricted to a small clique of elites and make upward social mobility equally less dependent on the fortunes of birth or political affiliation.

The more compelling argument for a developmental state has been offered by Bates, Avner and Singh (2002) and Bates (2006). Their classic presentation is a formal rejection of Hobbesian prediction of disorder in stateless societies. Backing their claims with several anthropological findings, they claim that what is absent in stateless societies is development. In other words, the absence of development is the price they have to pay for peace. The logic of their argument is simple. The people would rather stay poor to deter predation of their accumulated assets. The only way out of this under-development equilibrium is the establishment of a developmental state with strong and adequately compensated standing army that can ward off predators and secure private property. So it does not matter whether a state emerged from social contract as many elegant theories of political science will make us believe or is a product of conquest as many practical examples seems to suggest, a strong government with heavy involvement in the economy is required to initiate and sustain development.

In SSA and other transition countries, the minimum conditions for the operation of Coase theorem does not exist. Property rights are neither well-defined nor protected and transaction costs are excessively high. Yet some scholars (Rajan and Zingales 1995 \&2000, Far oubtswhether institutions would still not matter should the conditions for the operation of Coase theorem exist. But if we ignore their arguments, it is not difficult to prove why the absence of credible commitments would make it impossible for any market reforms to produce to any form of widespread prosperity.

Acemoglu, Johnson and Robinson (AJR) (2005) did provide an explanation why political Coase theorem does not work well. Their viewpoint rejected the possibility that all societies would pick efficient institutions. Furthermore they insisted that the choice of economic institutions will be determined by those who wield political power. How the surplus generated by the movement from inefficient to efficient institutions would be shared will to a large extent determine whether the process would be impeded or not. Since agreements reached with officials of the state cannot be enforced, beneficiaries of existing inefficient institution do not have any incentive to transit to a more efficient one. According to AJR (2005: p36)

"For example, economic institutions that enforce property rights by restricting state predation may not be in the interest of a ruler who wants to appropriate assets in the future. By establishing property rights, this ruler would be reducing his own future rents, so may well prefer economic institutions other than that which enforce private property. Therefore, equilibrium economic institutions will not be those that maximize the size of the overall pie, but the slice of the pie taken by the powerful groups.

Thus if market reforms are to produce successful results, political institutions that support efficient economic institutions of free market needed to be dealt with first and foremost. If that is not done, one should not expect that market reforms would on it own steam generate efficient institutions required for its success. Even when scholars appreciated the need for a strong institutional mechanism to support free market, they thought the best way to go about it was to first reform the markets and allow the market prompt the evolution of these efficient institutions. (Shleifer and Vishny 1998).

Another interesting dimension to the debate comes from the recent model developed by Rajan and Zingales (2006). Their model posits that initial factor endowments, and more specifically human capital endowments, might determine whether pro-market reforms would be advocated. The implication of this is that the possibility of any successful market reforms is slim except there is sizable middle-class. Though there was a rapid transition from socialist to capitalist mode of production from the republics of former U.S.SR and other East-European, and at comparatively lesser speed in SSA countries, there is no shred of evidence to show that this process was due entirely internal power dynamics. At any rate, market reforms produced disastrous consequences for virtually all transiting countries, whether the implementation was rapid or gradual.

Hoff and Stiglitz (2004) said the process of transition was accelerated at the instance of western scholars and international finance institutions. Accepting Rajan and Zingales argument still does make a strong case for a small government or minimalist state, and their work, in all fairness, was not intended to achieve that purpose but to show that underdevelopment is still possible in the absence of perverse institutional structure. A strong government is required to provide mass schooling (Goldin 2003). As they themselves argued, government for one reason or another, had to support education, for strengthening the army as it happens in France after their defeat in 1870 and as it happens in Korea in response to Japan colonialism. For purely ideological reasons and for the purpose of political socialization, communist countries promoted mass schooling.

If the size of the educated elite can determine the magnitude of support for market reforms as posited by Rajan and Zingales, it is certainly clear, that the post-market reform performances of many economies, both in SSA and former communist blocs, leave a bitter taste in the mouth. More than the constituency that push the reform process through would be required to guarantee it success. Political institutions, and the economic institutions it produces, will certainly matter for the success of markets. 
Going back to Shleifer (1998), we can easily understand why weak enforcement mechanisms which characterize institutionally weak societies make privatisation sub-optimal. Shleifer argument is that private ownership can hardly be superior to state ownership when contract enforcement is very weak. When political institutions cannot support economic institutions that enforce contracts, privatisation will only alter the form of rents obtained by beneficiaries. Those who extract rents will merely move from extracting rents directly from public enterprises to using the existing political influence to buy privatised firms and blocking competitions. If privatisation will generate economic surplus, it will be appropriated by the same group that enjoyed rents under the old order, except that income inequality situation will even be worse. If post-privatisation will produce any growth at all, it cannot be pro-poor.

We will present evidences to that effect in the next section. We will provide three important case-studies as evidence to show that market reforms in the form of privatization or any other form will produce little or no positive result in the absence of strong political institutions or at least ruled-based good governance. The tragedy that literally befell Russia and most other economies, and the poor performance of a good number of African countries after market reforms illustrate very vividly the limitations of free market in institutionally weak societies. The third instance is the misinterpretation of the rapid economic success of East Asian tigers as decisive victory for free market when there is minimal government intrusion into the economy.

\section{CASE ONE: MARKET REFORMS IN FORMER COMMUNIST ENCLAVES}

As stated earlier, most republics of the former Soviet Union adopted the 'big bang' method of reforms as against the gradualist approach of China with heavy government involvement. The argument in favour of this fast-track approach is that it is politically not possible to do so (Hoff and Stiglitz 2004) though countries of central Europe and the Baltic made the best efforts in establishing institutions and legal systems which curbed corruption and allowed markets to function relatively smoothly, with the exception of Czech and Slovakia (Svejnar 2002). Coincidentally, these are the countries which recorded respectable and sustained economic growth from the early to the mid-1990s. According to Svejnar (2002)

"All central European countries except for the Czech Republic have generated sustained economic growth since the early to mid-1990s. However, only in Poland has the rate of growth been sufficient to start closing the relative income gap with advanced OECD economies back toward its initial 1989 level. By 2001, every transition economy had an even larger relative income gap with the advanced economies than had existed in 1989." (p. 8)

Svejnar (2002) did divide the reforms into two categories- the type 1 and the type 2 reforms. In the type 1 market reforms, efforts were directed at macroeconomic stability, price liberalization and the pulling down of all forms of communist structures. Strategies adopted include restrictive macroeconomic policies, market pricing of goods and services, reducing subsidies to state-owned firms, removing barriers to establishment of new firms, move away from the culture of mono-banking and the introduction of social safety net.

In the type 2 package, we have the development and enforcement of laws, regulations and institutions to ensure the smooth functioning of the market system. Part of these reforms also included the privatization of large and medium-scaled firms, the development of strong banking system, establishment of appropriate regulatory system, and institutionalization of labour market regulations as well bodies responsible for public employment and retirement systems.

Though to varying degree, most countries of communist bloc proceeded well with type 1 reforms and for type 2 reforms, only seem to have done well with respect to mass privatization of state-owned firms. For institutions required to allow market to function and to protect the vulnerable, very little success has been recorded. For the Russia federation it offered its citizens little social insurance benefits and often could not afford to pay.

One discernible pattern in all of this is that countries with well-functioning legal systems and those that proceeded with privatization much slowly were able to avoid the catastrophic growth decline that accompanied the introduction of market economy. The growth decline was of course driven by a number of factors: poor corporate governance, capital flight, asset stripping, poor protection of property rights, macroeconomic instability etc, all of which are visible symptoms of institutional weakness. Unfortunately, macroeconomic stability was not immediately achieved for most of these countries.

According to Svejnar (2002), the income gap between the transition countries and counterparts in Western Europe has widened between 1989 and 1999. GDP per capita was only a paltry $\$ 620$ for Ukraine, $\$ 1250$ in Russia, \$4070 in Poland, \$5200 in Czech Republic and \$10000 in Slovenia (EBRD 2000). At the same time the GDP per capita for the US, 15 European countries and Japan were \$33000, \$22500 and 32600 respectively. Hoff and Stiglitz (2004) said that growth declined by 40\% in Russia between 1990 and 1996, an annual slide of 5.71\%.

Entering the transition phase without relatively strong political and economic institutions, communist blocs attempt to ensure macroeconomic stability was bound to fail. It was not surprising therefore that

"Poland, Slovenia, Albania, Bulgaria and Romania all experienced at least one year from 1990 to 1993 
when consumer price inflation exceeded 200 percent; Estonia, Latvia and Lithuania all had one year inflation around 1000 percent; Russia, Ukraine, and Kazakhstan experienced at least one year when inflation was above 2000 percent. Sometimes these bouts of inflation arose after lifting price controls: in other cases, inflation grew out of financial sector crises. (Svejnar 2002: 10).

The experience of these former communist enclaves only help to buttress some of very recent models developed by economists (Acemoglu et al 2003 and Henisz 2004) indicating that macroeconomic instability is a symptom of institutional weakness. Though Acemoglu et al work was essentially directed at the post-war growth experience of countries of Africa, Central and South America, which of course were characterised by crises of high inflation, unbearably large budget deficits and distorted exchange rates, the experiences are similar, and in some instance worse, for the transition economies. While it is common to view macroeconomic crises as product of poor policy choices, one lesson learnt from Acemoglu et al work is that the absence of institutions to curb political elites, ensure protection of property rights, create atmosphere of political stability and bring corruption down to the barest minimum, must be seen as the fundamental cause of the post-transition crises in communist enclaves, and as we shall soon see in the post-reform experiences of SSA.

In fact, once institution was controlled for in Acemoglu et al model, macroeconomic policies had insignificant impact on growth. Henisz (2004) reached similar conclusion. From a recent survey of firms in postcommunist countries by Johnson, McMillan and Woodruff (2002) found the weak property rights discourage firms from reinvesting their profits even when bank loans are available. Though external finance may be a useful source of finance in the face of internal scarcity of investment resources, institutional strength is important in determining the magnitude of such funds that are made available, and in the light of Johnson et al work, how much local entrepreneurs are willing to reinvest from profits retained.

The experience of these former communist countries shows that not much would have been lost, and in fact, a lot would have been gained, if the gradualist approach advocated by some scholars (Dewatripont and Roland 1992a, 1992b, 1995; Wei, 1997; McMillan and Naughton, 1992; Litwack and Qian, 1999) had been adopted. While the gradualism advocated by these scholars is in respect of policy reforms, the one at issue here is the need to entrench institutions that will make political elites accountable to the larger society, limits opportunities for initiating and sustaining poor policies, widen the scope of veto players (in some situations the use of direct democracy might be useful) in making policy choices, guaranteeing the independence of major organisations such as the central bank, the judiciary, the police, the electoral body etc and creating sufficiently competitive political markets that can discipline participants just like the private markets discipline consumers and producers alike.

The post-communist countries obviously did not go through this path. More importantly, those who secured great fortunes at the initial stage of the transition process are not in hurry to surrender their spoils. The regional elites still favour 'partial reform equilibrium' which limit the extent to which they can be held account to the larger society. This helps to retain the gains they obtained in the early phase of the transition (Stoner-Weiss 2001). Hoff and Stiglitz (2004) explained why mass privatisation in Russia did not produce pareto-efficient legal system as anticipated by some scholars. They said uncertainty about the legal regime can lead to asset stripping and asset stripping can provide incentive to block the introduction of the rule of law. Their explanation is particularly curious given the fact that efficient institutions are supposed to reduce, to the barest minimum, uncertainty in political, economic and social outcomes when agents interact(North 1990). Yet China, though a one-party state, has introduced important institutional reforms that have limited political opportunism and private uses of public interest (Woo 1993 and Qian and Weingast1997).

The good thing about efficient institution is that it makes pareto-inferior equilibrium unsustainable. Poor and growth inhibiting policies cannot persist for too, except that the economic cost is too minimal for anyone to be hurt. In Nigeria it was possible to introduce Sharia legal system because the overall federal structure was institutionally weak. With the bulk of government revenue coming from the south of the country but the revenue allocation system favouring the north (parameters such equality of development, land mass, population etc are used in the allocation of federally collected revenue), the introduction of Sharia legal system did not in any way hurt revenue available to the ruling elites from the northern states. In sharp contrast, the introduction of microautonomy by the Chinese government represents a fundamental institutional change which propelled, in sequential steps, further changes that accelerated growth (Lin, Cai and Li 1996).

CASE TWO: GROWTH PERFORMANCE OF AFRICAN COUNTRIES UNDER MARKET REFORMS Tragedy is the apt word used by Artadi and Sala-i-Martin (2003) to describe the post-independence development experience of many African countries, particularly those in the south of the Sahara. Yet without basis, except for the feuding nationalists waiting in the wings to replace the colonial masters, there was great optimism that postindependent Africa will bring about mass and unprecedented prosperity. Given that the resulting independent states were products of arbitrarily drawn boundaries bringing together many ethnic groups into one national space under compulsion and not consensus, economic performance in the $60 \mathrm{~s}$ and early $70 \mathrm{~s}$ can still be considered 
satisfactory, though below the economic performance of other emerging continents.

Quoting statistics from Maddison monumental work, Bloom and Sach (1998) said what represented Africa best moments are by world standard below average. Per capita GDP only grew by $1.5 \%$ in the $60 \mathrm{~s}, 0.8 \%$ in the $70 \mathrm{~s}$ and $-1.2 \%$ in the $80 \mathrm{~s}$. And between 1985 and 96 , per capita GDP further fell at an annual rate of $0.6 \%$. With few exceptions, growth has always been fuelled by favourable prices for commodity trade in the international markets. But if pre-market reform era, African economies were characterized by crushing poverty for the majority, embarrassingly level of income inequality, infrastructural decay among other things, nearly three decades of market reforms which was followed by semblance of multi-party democracy, do not appear to have improved living standards much and in other respect, particularly in terms of internal strife and conflict, situations became worse, as some countries in the continents of Africa were caught in the web of internal conflicts.

The market reforms have not altered the incentive structure of existing institutions in order that developmental states can emerge out of the fragile states already in existence. In fact, Artadi and Sala-i-Martin (2003) said for Nigeria, income inequality deteriorated, with more people sinking into poverty. Even under reforms, political leaders who benefited from the old order and who make policy decisions for the society did not have the right incentive to create institutional structure to enable mass prosperity since the economic misfortunes rarely affect them adversely. Given that we did not have the critical mass of well-educated people in Africa, it is doubtful if market reforms would have led to the evolution of efficient institutions if it did not emerge in former communist enclaves which had these big bang market reforms.

As advocated in the previous sub-section, building institutions should have been the first step and it can be followed by gradual or big bang approach to market reforms. In the absence of fundamental institutional changes, policymakers lacked the incentives to drive the development process. Policy reforms at first came at the instance of pressure from strong international organizations, and more importantly, it was accepted because the ruling elites would not be adversely affected. Specifically for Nigeria, and fortunately for the ruling cabal, the major casualties are the middle class persons, or appropriately put, the working class. Wages as a fraction of GDP in Nigeria was about $26 \%$ at the onset of the reforms of government. By the time Babangida was departing in 1992, it as dropped to a paltry $4 \%$ (Aigbokhan 2001). With what look like an emerging middle class nearly completely wiped out, the institutional capacity to control dictatorship and deter predation of public resources further diminished.

In the Nigerian case, the polarization of the society, as a result of clobbering of the middle class, unfortunately took an ethnic coloration because the bulk of educated persons who formed the crux of the middle class are from the Southern part of Nigeria. Beyond the cloak of ethnicity wrap around ruling elite-middle class debacle, the polarization of the society should be interpreted as a move to contain a possible source of opposition. It should be noted that strong opposition against federal military government led by Northerners or their ordained lackeys has frequently come from the south. While the direct use of coercive power was frequently used to contain the opposition, it was the market reform policies introduced by government that did the decisive damage to the economic fortunes of the middle class. Though the Nigerian middle class is by all standards docile, a growing middle class, particularly across ethnic groups, remain a potential source of threat to the political power of the ruling elites (Easterly 2001). Evenly spread middle class people across ethnic nationalities would have made ethnic politics less rewarding, because costly redistributive activities would undermine returns to their human capital endowments. Equally noteworthy is the possibility of significant reduction in the need to control the means of wealth transfer; political leadership. The alteration of the revenue allocation formula after oil became a major source of export earnings is a direct fallout of the absence of evenly distributed middle class across ethnic groups.

The deregulation of exchange rate created new opportunities for rents and led to the proliferation of banks due to high black market premium (Footnote: banks made a lot of money buying foreign exchange from official sources and selling it the black market. It is referred as round tripping) and the abolition of marketing boards in Nigeria in 1986 created unproductive millionaires overnight. These people do not have productive endowments but have the required political clout and ready access to rents. So bad was the situation that returns to education dropped to an abysmal 3\% (Oyelere 2006). At this time education was not a guatanteed route out of poverty. Economic policies that exposed the struggling manufacturing industry to unfair foreign competition, and in fact ruined a whole lot of them, were actively implemented. If not for anything, this was done as direct affront against a placid and complacent middle class.

Without any significant investment in human capital, exports would be barely restricted to commodities which do not require much skill. The devaluation of the Naira, the national currency did not therefore produce much gain outside the exports of agricultural commodities. Even for agricultural produce, the party didn't go on for too long before everything came to a sudden disappointing halt. According to Fadairo (2006), it did not take more than three years after the introduction of structural adjustment programme, when people of different kinds had gone into the business of exporting raw agricultural produce, before the market witnessed a dramatic slump. 
Efficient political and economic institutions would have prompted optimal private and public investment in human capital. The transition from an agrarian to an industrial economy would have been a lot easier. Exports of manufactures and capital goods, less subject to frequent price fluctuations, would have long become part of the feature of African economy. This would have reduced the vulnerability of the internal economy to external shocks. Generally, low-skilled individuals suffer greater income fluctuations through the lifecycle compared to their more educated counterparts.

The interests of the ruling elites and the metropolitan power are agreed on what policies could help contain the middle class. The stringent imposition of restrictions on expenditure profile of governments created ample opportunities not only to cut spending on public infrastructure in general, but to consistently under-fund education in particular. The expenditure cut did not deter predation of public resources, and in important instances excessive government spending was the norm. The 1991 oil-windfall is a specific case. According to Easterly (2001b), government spending rose by 50 percent in the early 1990s while school enrolment felled during the same period due to tight budget.

The failure to invest in human capital created ample opportunity for dictatorship to thrive and made it impossible to build an appropriate platform for participation in globalization that exploited the skills of productive workers to the advantage of national prosperity. In the absence of complementary human capital of the right kind and quality, foreign direct investment failed to flow. The little that came was essentially for the capital-intensive oil industry, which more often than not relied on foreign technical expertise to keep the industry running. By insisting that we should direct our education budget towards primary schooling without any shred of empirical evidences as to why we should do so, international finance organizations hoped to keep us out of the international markets for skilled-intensive products and services. Investment in mass education was required to get into the competitive world of exporting skilled-intensive products or services.

Since mass education would lead to strong and massive middle class, limiting the public funding of education was one viable mechanism of blocking this alternative power base. This is an African phenomenon and most likely accounts for her declining share of world trade since she could hardly compete in the exports of skill-intensive products and services that matter for rapid growth. Except for South Africa, most African countries south of the Sahara hardly export anything other than agricultural products and other low-value added minerals, whose prices are constantly fluctuating. The constant swing in the prices of these primaries accounts for the boom and bust cycle witnessed in these economies (Mkandiwire 2001). At least what is reassuring and offers window of hope is that the constancy and severity of this boom-bust cycle could be mitigated if the right approaches are adopted. Schultz (1975) long emphasized that the ability to deal with disequilibrium is to large extent determined by human capital endowment. The remarkable recoveries of East Asian tigers after the 1997 financial crises and that of Europe after World War II contrast sharply with Africa economic performance after more than three decades of market reforms. Yet aid supports to Africa are well above what the Marshall plan offered after the Second World War (O’Connell and Soludo 2001). While the market could be allowed to complement the efforts of government in providing schooling opportunities, it could hardly be relied upon for all of the schooling needs of the society.

The political control on the quality and quantity of public education allows the ruling elites to sustain power By failing to appropriately fund the mass education of its people, the ruling class can avoid a society with strong and large of middle class, and by extension the government would not have to depend on them to raise taxes required to run the state. In other words, the absence of a critical mass of middle class people, particularly in resource rich societies, renders governance unaccountable to the larger society. According to Bates, Greif and Singh (2002), the attainment of the equilibrium for a developmental state rests on the tenuous condition that the pay-offs to off-the-equilibrium path is low enough to deter predation. But this off-the-equilibrium path is conditional on the relative military capabilities of governments vis-à-vis private individuals remaining constant, government discount factor is not lowered, there is no rise in the state of insecurity, there exist an optimal tax rate, and public revenues cannot rise off-the-equilibrium path. For resource rich states with poor institutions, these conditions can hardly be fulfilled. Therefore, many of the states in Africa cannot, as presently constituted, overcome the Weingast paradox.

Just like government interventions are not justified for the simple reason that market failed, market-driven reforms cannot necessarily be the panacea for government failures. The fundamental nature of government failures is deeply rooted in conditions that trigger off-the-equilibrium behaviour on the part of the operators of the state. Market reforms are never the answer to these patterns of government failures. Market reforms not fully informed by the awareness of this wider and deep-rooted political context are exercises in futility and amounts to inflicting unnecessary pains on already impoverished people. Market reforms as being carried out will only purge the social welfare function of any remaining vestiges of equity, making government a less reliable partner in building a developmental state. The conclusion here is that we could avoid the heavy costs of market reforms if we attempted first to build institutions and then introduce these reforms later.

Market reforms worsen income inequality and further diminished the opportunity for creating strong and 
efficient institutions (Sokoloff and Engerman 2000; Engerman and Sokoloff 1997). Inequality further stunts growth, exacerbating poverty and worsening income inequality in a vicious cycle. It does appear that if the initial condition is that of unacceptably high level of inequality, market reforms should not have preceded profound institutional reforms. Those who have great access to wealth would block the emergence of institutions that secure the rule of law (Hoff and Stiglitz 2004).

The works of Sokoloff and Engerman argues that the initial level of income inequality could undermine economic development. They used their hypothesis to explain the huge growth gap between the development of Western Europe and Latin America. They posits that the initial unequal distribution of commodity endowments in Latin America played a major role in determining income inequality, and this inequality in turn created inefficient institutions. These endowments were relatively evenly distributed in North America and so did not constitute an impediment to development. The ruling elites opposed democracy and mass state-funded schooling because of the fear that the majority of the poor would become potential seekers of political power. However, North America the middle class promoted democracy and supported mass education of the generality of their people. The Nigerian experience, which to some extent may reflect the African situation, in the pre-market reform era was already characterised by high income inequality, due to the expropriation of the oil wealth by operators of the state. With the state apparatus already captured by private interests, market reforms only strengthened the grip of the ruling elites on virtually every apparatus of the state. If institutions are the first-order determinant of development (Acemoglu, Johnson and Robinson 2005) by creating the right incentives to create wealth, market reforms which worsen income inequality and make room for bad institutions cannot be expected to get Africa out of present economic morass, except we expect to ruled by benevolent social planners, the likes of which we frequently encounter in textbooks of welfare economics but which we rarely encounter in real life.(footnote: But we will return to the subject of the benevolent social planner in the subsequent section when we discuss the place of governance in development).

The experience of transition economies, which is also relevant here, is how firms have shape the rules of the game to their own advantage and at significant cost to society (Hellman, Jones and Kaufman 2003). In their model, public officials and politicians sell under-provided public goods and other rent-generating benefits to individual firms. They called this state capture as against influence peddling (getting the same thing done without having to pay) and administrative corruption which the collection of bribes by public officials to influence the implementation of laws and regulations. Prior to reforms, some firms have influence on the state and therefore enjoy secure property and contractual rights as well as higher growth rates. In order to gain footage, new entrants turn to state capture as a strategic choice. When the state under-provides opportunity for entry and competition, new firms resort to buying from the states the privileges of having secure property rights and removal of obstacles to improved profits. Curiously, and this is in line with the argument of this paper, Hellman et al 2003 advocated that improvements in civil liberties can help reduce the extent of state capture by $15-30 \%$ percentage points. This implies improving civil liberties will also boost economic growth. In fact their work did emphasise that state capture, while generating enormous private benefits to captor firms, nevertheless reduce growth rates by $10 \%$ over a three year period. The roles of multi-national corporations in undermining development in developing countries of Africa are well-documented in the literature (see Nkrumah.... and Fourth Dimension publisher, Rodney Walter....for several well-documented cases) long before the era of market reforms.

Since the political influence of local power elites and international business interests are not going to be fundamentally negatively affected by the reforms, there was no need to resist these, more so in the face of persistent macroeconomic instability, mounting budget and balance of payment deficits. Even then, the halting manner in which the policy reforms were implemented, and sometimes complete policy reversals by government, basically reflects the institutional weakness of the policy environment. We will return to this issue later.

The market reforms as packaged by international finance organizations became perfect escape route for economic crises that needed fundamental institutional change. Though coming late, these organisations seem to have realised the role efficient institutions and good governance play in accelerating development. However, their institutional and governance agenda are not as clear cut as their much touted market reforms. What they drive more often than not are the market reforms. There is yet no firm resolve on how to tackle the problem of credible commitments in the political arena, so that political leaders off-optimum equilibrium strategies will most certainly generated zero payoff. More than the massive transfer of aid to developing countries, which in any case weaken institutions and undermine accountability, efforts directed at helping poor countries create a culture of credible commitments on the path of political leaders will certainly yield significant economic payoffs to the larger society.

The analysis by Ndulu and O'Connell (1999) is very instructive. Their study covered the trend in the GDP per capita between 1960 to 1997 across three specific regime types; countries with multi-party system, one-party system and others with military oligarchies. Countries with multi-party democracies had the most impressive growth records, and are now there are while they know their lowest anywhere, predictably; countries with 
military oligarchies recorded the worst performance. The disappointing performance of countries under military oligarchies, of which Nigeria is a prominent member, could be explained by the fact that institutional constraints are weakest in these countries. Because neopatrimonial exchanges are well-entrenched in these countries, costly and growth-inhibiting redistributive practices often characterised the polity. In some cases, metropolitan powers were involved in overthrowing democratic regimes in early post-independent Africa and establishing full-blown dictatorship. In one specific instance, western donors made generous payments to Mobutu of Zaire to keep socialism at bay (Acemoglu 2006 for proper reference) and actively supported political assassinations (Jones and Olken 2007).

There are different ways the growth slowdown in developing countries after decades of policy reforms is being interpreted. Some see it as a case of policy failure ( Krugman) and others argue that international financial agencies have essentially undermined the growth of young economies (see Mkandiwire 2001 for review of these arguments) If either representative or participatory democracy is required for rapid economic growth and structural change in the economy, there is no link between these policy reforms and existing state structures to suggest that is possible. According to Mkandiwire (2001)

"The state-structure side of the definition of the developmental state emphasizes capacity to implement economic policies sagaciously and effectively. Such a capacity is determined by the various others-institutional, technical, administrative and political. Undergirding all these is the autonomy of the state from social forces so that it can use these capacities to devise long-term economic policies unencumbered by claims of myopic private" (p.290)

What is therefore important is the need to build these capacities, beyond the hurried implementation of reforms which produced disastrous consequences. In fact these capacities are built by strong states. The important question of while some societies build strong states while others don't is outside the scope of our analysis, but Besley and Persson (2007) did say that fighting external wars, the need for political stability and inclusive political institutions push some nations to build state capacities. Efficient political cum economic institutions drive state capacities, and state capacities determine to a large extent the type of policy reforms to be adopted as well as the success or otherwise of these policy reforms.

The appropriateness of these policy reforms is also being raised. The Institute for Africa Alternatives (IFAA) has been at the forefront of challenging the policy prescriptions of IMF and World Bank. Aside this, Krugman (1995) said all countries that implemented the Washington consensus policies recorded disappointing economic performance. However, Stiglitz (......) maintained that the countries that succeeded are the ones that never implemented the World Bank approved economic reforms. In this case, both the prevailing institutional structure and the enforced policy reforms are inappropriate for getting SSA out of her economic misfortunes. However under the existing institutional framework, poor policies could be sustained for so long because policy makers cannot be penalised for sustaining them. In other words, the tendency to adopt optimal policy in the long run does not exist because inefficient institutions lack the capacity to drive the process. This is the main reason why policies that redistribute away from the poor towards the rich characterized the African polity as observed by Bates (1981). The market policy reforms starting in the 1980s have retained similar redistributive characteristic. While is it true that some populist policies may be growth-inhibiting, what has however characterized the African political economy, and more specifically the Nigerian polity, are policies that benefit a small group of people. Though revenue derived from the Niger Delta rich oil resources are being used to run the Nigerian state, the revenue allocation formula has favoured the Northern part of country. Paradoxically, the North still lags far behind the south, and post-independent disparities in development have not substantially diminished (Wantchekon and Assmarin 2006.....).

While macroeconomic instability is essentially symptomatic of basic institutional weakness, responses to these macroeconomic shocks are equally inappropriate for the same reason. Therefore both pre- and post-reform policies were equally damaging. Artadi and Sala-i-Martin (2003) did say that since the ruling elites were not in serious way affected by the downturn in the economy, there existed no incentive to adopt the right policies to reverse the trend. The reforms were never introduced to spur pro-poor growth, and therefore there frequent reversals were only done at the instance of widespread, opposition which could lead to loss of power. The African situation was not that of a benevolent social planner faced with time-inconsistency problem (Kydland and Prescott 1977), but that of unconstrained and corrupt ruling elites making all efforts to sustain their access to rents. The market reforms which started in the 1980s should be seen in that light. For Africa, market reforms further diminish already weak institutions of state.

For much of the last three decades, there has been no fundamental institutional restructuring of African states, except for the wave of transition to civil rule, not constitutional democracy as such, blowing across Africa. For Nigeria in particular, civilian rule was grafted onto a rickety federal structure, with an overbearing central government amidst weak states and local governments. Such arrangement could not create the condition required for the alignment of both revenues and expenditures of constituent states. Yet such alignment is required for optimal fiscal policy in multi-state federal system (Osayimwese and Iyare 1991). If we started with 
fundamental institutional reforms, poverty-reducing policies would naturally have followed suit. Civilian rule would also have produced widespread economic benefits. The possibility of getting positive and substantial payoffs from lack of credible commitments would have been eliminated outright, or least significantly minimized. (footnote: Aryeetey (1994) sees low credibility as the main reason why investors did not respond much to the incentives offered by Ghana market reform policies). The destructive competition for rents when socially suboptimal equilibrium strategies are viable options, and the attendant adverse consequences for general welfare, could also have been avoided.

Efforts at building institutions would have yielded positive payoffs for the barely visible and neglected rural populace whose aspirations are most often not reflected in the social welfare function. Instead of rents being extracted from the rural population, resource could be skewed in their favour under representative democracy in a way that is pareto-improving. Stasavage (2005) reports that democratic governance has raised political supports for primary schooling in the rural areas in Africa. This has been more pronounced in Uganda than elsewhere in Africa. While the immediate cause of growth could be human capital, what prompts this human capital investment is the presence of good institutions. More importantly, widespread universal primary schooling could have helped to integrate the essentially unregulated informal economy into the formal sector of the economy. The educated are more likely to work in the formal sector where basic and advance skills are much more required than the informal sector. That would help the market economies, or any market reforms that would be introduced later. But competitive party politics which could drive the process has been impeded by market reforms which came first in the sequence of reforms. Initial gainers from the market reforms opposed rather than support the evolution of efficient institutions.

Though a large number of empirical studies have shown that institutions are generally growth-enhancing (see Acemoglu, Johnson and Robinson (2005), Glaeser et al (2004) have recently argued that human capital is the reason why new settler colonies such Canada, New Zealand, USA, and Australia experienced development rather than the presence of good institutions. Though the former viewpoint has an overwhelmingly large amount of evidence in it favour, it is difficult to think of how market reforms could have fostered optimal human capital investment given the merit-good characteristic of schooling. However, whichever viewpoint is right is not important for us in this analysis, but market reforms seem incapable of fostering neither optimal schooling nor good institutions.

An elitist rather than an egalitarian school system would most likely be the outcome when market reforms precede the establishment of good institutions. This is a school system characterised by poor quality public schooling for the majority side-by-side with high quality private schooling for the privileged few. What is more, an elitist school system can impede the emergence of good institutions in order to block the opportunity for future emergence of an alternative source of political competition outside of the existing power structure. There are also no viable formal financial markets to access funds for schooling, and even if they do exist, the poor are least likely to access such funds. Thus, an elitist system can prevent an optimal investment in schooling, and block efficient institutions.

The designers of market reforms did not seem to have taken into consideration the important issue of power configuration in exchange relationship. Since the pro-market reformists took the prescriptions from traditional economics, it was not surprising that they never took into consideration how unequal power distribution between parties in economic transactions would matter for outcome. Coase theorem, they thought, would always work out an efficient outcome. In other words, the allocation of rights or legal liability cannot determine outcomes when parties can transact at little costs. However, power will always be important, more so when income inequality is high and inefficient institution exist. According to Bowles and Gintis (2000),

"The first implication is that where some aspect of an exchange is not subject to a costlessly enforceable contract, social norms and psychological dispositions extending beyond the selfish motives of Homo economicus may have an important bearing on outcomes, even in competitive markets. The second implication is that market outcomes depend on strategic interactions in which something akin to "power" in the political sense is exercised. ... The result of these two consequences of incomplete contracts is that economic analysis must become more social and psychological in its treatment of the human actor, more institutional in its description of the exchange process, yet no less analytical in its model-building and no less dedicated to the construction of general equilibrium models. (p. 1412)

If power will matter in competitive markets, it will matter a lot more in highly imperfect markets of Africa. The power configuration determines eventual placement in the hierarchy (Demsetz 1972), who controls the production process (Marglin 1974), and who holds the ace when labour markets do not clear (Gintis 1976; Shapiro and Stiglitz 1984). The contingent renewal models of principal-agent also help to highlight the place of power in exchange relationship (Bowles and Gintis 2000). They help to show why workers would choose greater level of effort than they would ordinarily have done in the absence of threat. One party to the contract would always be constrained, and would therefore not be able to secure desirable contract terms. In essence, tenantlandlord, creditor-debtor, employer-employee and other forms of contractual relationships will result in sub- 
optimal outcomes. Place in the context of market reforms in developing countries, it is possible for the wealthy and politically powerful to subvert the operation of legal, political and regulatory organisations.

Glaeser, Scheinkman and Shleifer (2003) model allow us to see how inequality in economic and political resources can lead to institutional subversion. Furthermore, they showed how the subversion of institutional process lowers capital accumulation and poor growth. Of course, if the outcome of legal disputes is resolved in favour of the wealthy and politically powerful, the incentive for the politically powerless to invest is diminished by poor property protection, resulting in poor growth. Glaeser et al used their model to explain why growth slowed in the US during the Gilded Age relative to other periods. Yet the institutional inefficiency of this period came to a halt in response to a major political intervention. The political interventions came in the forms of rising taxation and regulation; regulation of commerce, anti-trust laws, the securities laws and other types of intervention. The central focus of the political interventions was the elimination of rents which the subversion of the institutional process has brought about.

It is not clear how market reforms would affect ethics, particularly ethics that encourage widespread growth and income equality. But when market reforms are introduced at a time public and private morality is at it lowest, the impact on growth can be negative. When public organisations have infamous reputation for corruption, the wider implication is to further suck in the morally upright into the corruption network, depressing growth and rendering institutions essentially ineffective. Extensive corruption penalises honest conducts which can support functional and growth-promoting markets. Though market reforms could eliminate some forms of corruption, \{Footnote: the advocacy for market reforms is premised on the fact that big government, measured in terms of government spending as percentage of GDP, is the reason for widespread corruption (Mbaku 1998). However, and as noted by (Tanzi 1998), countries with the largest public sectors such as Sweden, Canada, Denmark, Netherlands, Finland are also one of the least corrupt countries in the world \} one possibility that cannot be ruled out is that is the transformation of nature of corruption; that is, ethically debased men would relocate to other kinds of corruption where rents could be appropriated. The public-private sector inter-phase is one great opportunity for collusive corruption, which though may benefit parties involved, but in many instances are socially harmful. It could also happen as the marginal benefits of government expenditures fall drastically as huge kickbacks are paid to public officials in charge of awarding public contracts.

One other avenue through which this can happen is when public revenue falls drastically because parties involved in transactions short-change the government of deserved revenues for personal benefits. Thus, many growth enhancing public projects cannot be undertaken because public revenues cannot support these projects. Billion of dollars of public funds have been transferred out of Nigeria because the weakly regulated private banking sector has been willing co-operators and beneficiaries with thieving public officials. Institutional constraints that limit or eliminate this kind of privately beneficial transactions would raise social welfare. But market reforms cannot give birth to these institutional constraints. Though growth overtime may provide incentives to invest in the emergence of efficient institution (Shleifer 2004), but the nature of growth and the accompanying income distribution pattern are ultimately the determining factors of emergent institutional arrangement. Rising output combined with income inequality cannot produce efficient institution, not even in the long run. In fact, under-development equilibrium may actually become permanent feature of any economy in which initial income distribution pattern have entrenched strong political influence which may be difficult to break.

Market reforms seem incapable of dealing with the peculiar problems of multi-ethnic societies. The general trend in the literature is that ethnic fractionalization or polarization undermine development process (see recent review by Alesina and La Ferrara 2005) by raising the transaction costs between groups, causing decay in social capital, promoting conflicts, entrenching corruption, reducing growth promoting cooperation, and foisting a regime of dysfunctional macroeconomic policies. Since ethnic diversity generally undermines the state and weakens its operator, the government, it is difficult to see how weak government and the state can support the market. With geographical and occupational immobility of ethnic groups being the norm, it is possible to use the apparatus of the state to target ethnic groups, either for rewards or for punishments. It is equally possible to transfer resources from one group to another. When ethnic groups are geographically fixed or a particular group is exclusively involved in specific profession or trade or industry, market reforms will not just produce winners and losers across different groups, but will produce distinct ethnic winners and losers. The larger the size of loss or gains from market reforms, the greater the contest for political power, particularly when government is not constrained.

Political instability associated with this kind of bitter contest for power is often reflected in frequent policy reversals. These policy reversals are as prevalent within specific regime as between regimes. In institutionally weak societies, there are fewer economic opportunities outside clientelist relationships with government, making the contest for power even keener and influence buying more important. Policy reversals are often a reflection of dominant ethnic groups with access to power and influence. As public officials are rotated within public offices, they must create rents for their ethnic supporters. Therefore, markets cannot be free and market reforms cannot 
work.

Institutional reforms that increase significantly the size of the selectorate that influence policy decision of government will have greater impact on welfare than market reforms when the size of the selectorate is small. The model of Lizzeri and Persico (2001) illustrates this fact well. The smaller the size of the selectorate, the cheaper it is for rent-maximizing government to transfer private goods to this selectorate and under-provide public goods needed by the larger majority. In African societies, the selectorate are representatives of ethnic groups. When various ethnic groups are represented by these selectorate, neither national nor regional public goods are optimally provided. Since limited national public good provision, for example the railway, limits beneficial inter-group interaction and mobility from one region to another, market reforms accentuate interethnic group frictions. This limits the possibilities of success for market reforms.

Though may not cure all ills, good institutions will mitigate the debilitating effects of ethnic fractionalization (Williams 2001). Furthermore, Williams did say institutions that respect the rights of the minorities and specify business rules unambiguously will be more valuable in ethnically heterogeneous society than homogenous ones. This is because Kin selection that bond people within specific ethnic group, and which can be a good replacement for formal institutions that enforce contracts, is absence between groups. Luigi, Sapienza and Zingales (2004) found that lower relative levels of trusts leads to less trade, less portfolio investment and less direct investment with countries/groups held in distrust. The impact is even more significant for trust-intensive goods. However, the level of trust is associated with religion, history of conflicts and genetic similarities.

\section{CASE THREE: ECONOMIC MIRACLE IN EAST ASIA.}

The phenomenal growth in the economies of East Asia has generated a lot of debate among scholars. While some have seen this growth miracle as evidence of the effectiveness of either protectionist policies or outward oriented policies, others see it as product of appropriate government intervention or free-market policies, with minimal government. Furthermore, some of the arguments have centred on whether factor accumulation or growth in total factor productivity propelled the growth (see Frankel and Romer 1999 and 2006 for a brief survey of these viewpoints). As far as this piece is concerned, a combination of factors has helped to accelerate growth in East Asia. But from all the evidence available, the least likely reason for this peculiar growth experience is due to laissez-faire policies. Therefore, it "economic miracle" within a period of two decades cannot be representing a testimony to the power of free market to produce the needed prosperity. Big governments have been at the roots of developments in these countries. Intervention measures have been appropriate and support for business has been consistent. The mere fact that none of the four Asian tigers were really established democracies in the 1960s, when their development process gathered momentum, cannot play down the role of institutions in fostering prosperity. In fact Singapore which then was and still is a democracy is often referred to civilian dictatorship (Acemoglu and Robinson 2006). As we would soon see, a combination of internal and extermination factors influence the institutional structure as well as the policy choice of political leaders to produce mass prosperity of the magnitude witnessed today.

Though economics is a non-laboratory science, which does not permit experiments which the natural scientists in the fields of physics and chemistry are frequently carrying out, natural events do throw themselves up in such a way as to allow us study economic situations just like natural scientists would. The introduction of socialism in former soviet republics and it consequent spread to other parts of the world is one natural experiment. It allowed the comparison of the economic performances of socialist and capitalistic economies. One spectacular opportunity came in the mould of the split in Korea into two separate republics after the second war ended. It was divided into the capitalist North and socialist South. Though the results may not be given sweeping generalisation, but the divergent growth paths of the two economies after five decades would allow us to determine the role played by these different economic systems in affecting economic outcomes. Since these economies are alike in almost every respect, it is possible to interpret the vast variation in their performances as being due to the different political and economic institutions they adopted after the second war.

According to Acemoglu et al (2005) North Korea was relatively more prosperous than the South, though there was little geographic difference between them. The North has better endowments of natural resources, but both have equal access to markets and face the same costs of transportation. The North was more industrialized at the time. At the time they separated, both had roughly the same income per capita. While culture, geography and other country characteristics remained the same for these two countries, there political and economic institutions changed after there separation. Five and half decades after separation, the income per capita for South Korea had reached $\$ 16000$ while of the North was only a paltry $\$ 1000$. While the South had joined the league of developed countries, the North still remained at the backwater of development. The same experience is replicated in East Germany and West Germany, before their reunification in 1989.

Though the institutions that prompt growth were not deliberately put in place as was the case in Western democracies, the circumstances of the time created an institutional matrix that compel development. For 
Engerman and Sokoloff (ES), at the take-off point for these Asian tigers, the level of income inequality was not particularly as to create a strong constituency that will impede the growth process. Though Philippines and South Korea were at the same level of development in the $60 \mathrm{~s}$, the latter country accelerated economic development while the former stagnated. According to ES, there was greater income inequality in Philippines compared to South Korea though both countries were ruled by dictators. Thus, initial pattern of income distribution would be an important part of the explanation, not of economic development per se, but why the development process was not impeded.

Equally worthy of consideration is the role played by good policies (Frankel and Romer 1999, 2006). These authors (Frankel and Romer) place a great deal of stock on good policies, particularly the adoption of outwardoriented strategies, as being favourable to growth. But the important question is what "are the determinants of good policies"? Why do some countries choose good policies while many others do not seem to get it right? Something must be mediating the good policies adopted by these Asian tigers. Good policies themselves are not natural endowments like land and mineral resources. They constitute deliberate choices of policymakers. Like physical capital, policies are man-made. Thus, capital and good policies can only be proximate causes of development, not the underlying reasons. What must be responsible for development must account for why countries acquire more or less of man-made capital, and furthermore, why they adopt good policies. Institutions can help explained this, or at least form an important part of this explanation. According to North (1990)

"But the general points I wish to make here are, I believe, quite clear: (1) the institutional framework will shape the direction of the acquisition of knowledge and skills and (2) that direction will be the decisive factor for the long-run development of that society. If the firm or other economic organisation invests in knowledge that increases the productivity of the physical or human capital inputs or improves the tacit knowledge of the entrepreneurs, then the resultant productivity increase is also consistent with the growth of the economy. But what if maximizing behavior by the firm consists of burning down or sabotaging competitors, or of labor organizations engaging in slowdowns or makework, or farmers getting the government to restrict farm output and raise prices?(p.78)

The evolutionary growth-path of banking in the US and Mexico can help to highlight the value of appropriate institutions in fostering development. Haber (2001: 9) reports that as at 1818, the US had 338 banks with a total capital of \$160million. In 1860 the number grew to1579 and reached 27864 in 1914 with a staggering total assets base of $\$ 27.3 \mathrm{bn}$. Similarly Mexico in 1910 had 42 banks which operated as segmented monopolies, with only two of them controlling $60 \%$ of total banking assets. At the outset of the American state, it constitution had allowed the segmentation of state-owned banks which allowed the sharing of rents with state. Thus, at the beginning, the American banking system was very much like the Mexican. However, the federal system in America made a remarkable impact, making this kind of banking system unsustainable. The competing states in America were forced to allow competitive banking system as they competed for investment and migrants. Under the centralised system in Mexico, the best way to raise revenue was to grant monopoly rights. The substantial growth gap between US and Mexico which opened up in the early years of 1900s could be traced to the political institutions that support competitive market system in one society and undermined it in another.

For these pro-market East Asian economies, the threat of communism was real. The possibility that communism could spread meant that they had to radically developed their economies and reduce substantially the poverty levels of their people. The communist North Korea was a constant threat to Park's South Korea, just the Mao's growing grip on China made Kai unsafe in Taiwan. For South Korea communist elements were also growing within the polity. The possibility of external invasion by communist neighbours played the same role inter-country wars played in Europe in forcing countries to modernise their institutions or transit to an efficient (Besley 2007). For Europe, this process was assisted by the absence of strong international organization such as League of Nations or the United nations, which can mediate international conflicts (Bates, Avner and Singh 2002). For the Asian tigers, UN was still very young, and more importantly, was also polarised along the communist-capitalist ideological divide. External conflicts force countries to develop inclusive governance and institutional matrix. This is due to the fact that success in external wars is partly dependent on internal cohesion, which most likely cannot exist in institutionally weak societies. In the case of Taiwan, a highly corrupt $\underline{\text { Shek Kai }}$ in China overnight became a fierce fighter of corruption in Taiwan, the place to which he fled with his numerous supporters after he lost out in the power struggle to Chairman Mao.

The relative homogeneity of these Asian tigers made it possible for them to avoid the adverse consequences of ethnic diversity on economic development, particularly it corrosive effects on institutions. The transaction costs of inter-ethnic cooperation, and in the special case of Malaysia, political arrangement helped doused ethnic riots which engulfed them in the early years of independence. With their lesser natural resource endowments when compared to Africa, the tendency toward extracting the resources of one geographically immobile ethnic group to favour another group is not a characteristic feature of these economies. Though rent-seeking was prevalent in Asia (Tullock 1967 Krueger 1974), it is debatable whether their impact on growth is as adverse as portrayed in the literature (Mkandawire 2001). The argument of Mkandawire is that the adverse relationship 
between rent-seeking and growth is because rents are often treated as exogenous to the firm them. If the assumption of exogenous rents is dropped in favour of endogenous rents, one in which the rents are a function of firm's activities, then the relationship between rents and growth take a positive turn. Rents now become a function of firm performance. More productive firms generate more rents. The competition therefore spurs growth and does not hinder it. Bellin (1994) also concluded in a study on Tunisia that government as a channel of extensive clientelist practices, under appropriate political institutions, can accelerate growth. Ultimately, what will matter is the nature of political institutions which support growth-promoting economic institutions. The next section will therefore discuss briefly key political institution variables that can drive economic development.

\section{PENULTIMATE SECTION-AREAS OF INSTITUTIONAL REFORMS}

*Curbing corruption or abuse of office.

*Independence of controlling agencies

*Media Freedom

*Direct Democracy

*Protection of private property rights.

*Rendering governance accountable.

*Accountable political parties

*Free and fair elections

*Ethnic reorganization-using human capital externalities to dilute ethnic loyalties which inhibit growth.

\section{LAST SECTION: SUMMARY AND CONCLUSIONS}

Acemoglu Daron, S. Johnson and J. Robinson (2005). Institutions as the Fundamental Cause of Long-Run Growth, in Handbook of Economic Growth (eds) P. Aghion and S. Durlauf, North-Holland.

Acemoglu Daron, S. Johnson, J. Robinson and Y. Thaicharoen (2003). Institutional Causes, Macroeconomic Symptoms: Volatility, Crises and Growth, Vol. 50, No. 1: 29-123.

Acemoglu Daron and J. Robinson (2006) Economic Origin of Democracy and Dictatorship, Cambridge; Cambridge University Press.

Alchian Armen and Demsetz Harold (1972). Production, information costs and Economic Organisation, American Economic Review, LXII:777-795

Alesina Alberto and Eliana La Ferrara (2005) Ethnic Diversity and Economic Performance, Vol. XLIII: $752-800$.

Artadi Elsa V and Xavier Sala-i-Martin (2003). The Economic Tragedy of the $\mathrm{XX}^{\text {th }}$ Century: Growth in Africa, National Bureau of Economic Research Working Paper No.9865.

Aryeetey George (1994) Private Investment Under Uncertainty in Ghana, World Dvelopment, Vol. 22, No. 8: 1211-21.

Bates Robert H (2006). The Developmental States, in Oxford Book of Political Economy, (eds) Barry Weingast and Donald Wittman. New York: Oxford University Press.

Bates Robert, Avner Greif, and S. Singh (2002). Organizing Violence. Journal of Conflict Resolution, Vol. 46, No 5: 599-628.

Bates Robert (1981). Markets and States in Tropical Africa. Berkeley: University of California Press.

Bellin E. (1994). The Politics of Profits in Tunisia: Utility of the Rentier Paradigm, World Development, Vol. 22: 427-436.

Besley Timothy and Torsten Persson (2007). The Origins of State Capacity: Property Rights, Taxation and Politics, National Bureau of Economic Research Working Paper w13028.

Bloom David and Jeffrry Sach (1998). Geography, Demography and Economic Growth in Africa, Brookings Papers on Economic Activity, 2:207-295.

Bowles Samuel and Herbert Gintis (2000). Walrasian Economics in Retrospect, Quarterly Journal of Economics, November: 1411-1439.

Dewatripont, Mathias and G. Roland (1992a) Economic Reform and Dynamic Political Constraints, Review of Economic Studies, Vol. 59, No. 4: 703-30.

Dewatripont, Mathias and G. Roland (1992b). The Virtues of Gradualism and Legitimacy in the Transition to a Market Economy, Economic Journal, Vol. 102, No. 411:291-300.

Dewatripont, Mathias and G. Roland (1995) The Design of Reform Packages under Uncertainty, American Economic Review, Vol. 85, No.5: 703-30.

Easterly William (2001) The Middle Class Consensus and Economic Development, Journal of Economic Growth, 6: 317-335.

EBRD (2000) Transition Report. London: European Bank for Reconstruction and Development.

Fadairo Opeyemi O. (2006) Impact of Exchange Rate Policy on Non-Oil Exports in the Nigerian Economy (1970-2004), Unpublished Final Year Project, Covenant University.

Engerman S. and K. Sokoloff (1997). Factor Endowments, Institutions, and Differential Paths of Growth 
Among New World Economics: A View from Economic Historians of the United States, in Stephen Haber (ed), How Latin America Fell Behind, Standard CA: Standard University Press.

Farrell Joseph (1987). Information and Coase Theorem, Journal of Economic Perspectives, Vol. 1:113-129.

Frankel Jeffrey, D. Romer and T. Cyrus (2006)) "Trade and Growth in East Asian Countries: Cause and Effect?" in NICs After Asian Miracle, New World Order Series, vol. 23, edited by H. Singer, N. Hatti and R. Tandon, BR Publishing Corporation (India) Ltd.

Frankel Jeffrey, D. Romer and T. Cyrus (1999). Does Trade Cause Growth? American Economic Review, Vol. 89, No. 3: 379-399.

Gintis Herbert (1976) The Nature of the Labor Exchange and the Theory of Capitalist Production, Review of Radical Political Economics, VIII: 36-54.

Goldin (2003). Mass Secondary Schooling and the State: The Role of State Compulsion in the High Movement, National Bureau of Economic Research Working Paper 10075.

Glaeser E, R. La Porta, F. Lopez-De-Silanes and A. Shleifer (2004). Do Institutions Cause Growth? Journal of Economic Growth, Vol. 9: 271-303.

Glaeser E, J. Scheinkman and A. Shleifer (2003). The Injustice of Inequality, Journal of Monetary Economics, Vol. 50: 199-222.

Haber Stephen (2002). Political Institutions and Banking Systems: Lessons from the Economic Histories of Mexico and the United States, 1790-1914, Unpublished, Department of Political Science, Stanford University.

Henisz Witold J. (2004). Political Institutions and Policy Volatility, Economics and Politics, Vol. 16, No. 1: 127.

Kayode M.O (2004) Towards A Re-birth of Nigeria's Economic Development, Fifth Annual Public Lecture of the Nigerian Economic Society delivered at Nicon-Hilton, Abuja, $24^{\text {th }}$ February 2004.

Krueger Anne O.(1974) The Political Economy of Rent-Seeking Society, American Economic Review, 64: 291303.

Krueger Anne O.(1990). Government Failures in Development, Journal of Economic Perspectives, Vol. 4, No. 3: 9-23.

Krugman Paul (1995). Dutch Tulips and Emerging Markets, Foreign Affairs 74: 23-44.

Kyland Finn and Edward Prescott (1977). Rules rather than Discretion: The Inconsistency of optimal Plans, Journal of Political Economy, Vol. 85 No.3:473-492.

Jones Benjamin and Benjamin Olkens (2007). Hit or Miss? Effect of Assassinations on Institutions and War, National Bureau of Economic Research Working Paper No. 13102.

Lin Justin Y, Fang Cai and Zhou Li (1996). The Lessons of China's Transition to a Market Economy, Cato Journal, Vol. 16, No. 2:1-26

Litwack John and Y. Qian (1998). Balanced or Unbalanced Development: Special Economic Zones as Catalyst for Transition, Journal of Comparative Economics, 26 (1): 117-41.

Lizzeri A. and N. Persico (2001). The Provision of Public Goods under Alternative Electoral Incentives, American Economic Review 91, 225-245.

Luigi Guiso, P. Sapienza and L. Zingales (2004). Cultural Biases in Economic Exchange, National Bureau of Economic Research Working Paper w11005.

Mbaku Mukum (1996). Bureaucratic Corruption in Africa: The Futility of Cleanups, Cato Journal, Vol. 16, No. 1: $1-16$.

McMillan John and Barry Naughton (1992). How to Reform a Planned Economy: Lessons from China, Oxford Review of Economic Policy, Vol. 8, No. 1: 130-43.

North Douglas (1990). Institutions, Institutional Change and Economic Performance, Cambridge University Press.

Mkandawire Thandika (2001) Thinking About Developmental States in Africa, Cambridge Journal of Economics, 25:289-313.

Ndulu Benno J. and Stephen O'Connell (1999). Governance and Growth in Sub-Saharan Africa, Journal of Economic Perspectives, Vol. 13, No 3: 41-66.

North Douglas and Barry Weingast (1989) Constitutions and Commitment: The Evolution of Institutions Governing Public Choice in Seventeenth-Century England, Journal of Economic History, Vo. XLIX, and No.4:803-832.

North Douglas (1990). Institutions, Institutional Change and Economic Performance. Cambridge, Massachusetts: Cambridge University Press.

Osayimwese Izevbuva and Sunday Iyare (1991). The Economics of Nigerian Federalism: Selected Issues in Economic Management, Vol. 21, No. 4: 89-101.

Oyelere Ruth (2006) The Returns to Education Enigma, forthcoming in the Journal of Development Economics.

QianYingyi and BarryWeingast (1998). The Market-Preserving Federalism, Journal of Economic Perspectives, 
Vol.11, No.4:83-92.

Rajan Raghuram and Luigi Zingales (1995). The Tyranny of the Inefficient: An Enquiry into the Adverse Consequences of Power Struggles, National Bureau of Economic Research, Working Paper 5396.

Rajan Raghuram and Luigi Zingales (2000). The Tyranny of the Inequality, Journal of Public Economics, Vol. 76, No. 3: 521-558.

Roland Gerard (2002) The Political Economy of Transition, Journal of Economic Perspectives, Vol., 16, No. $1: 29-50$

Shapiro, Carl and Joseph Stiglitz (1984). Unemployment as a Worker Discipline Device, American Economic Review, LXXIV: 433-444.

Shleifer Andrei (1998) State versus Private Ownership, Journal of Economic Perspectives, Vol. 12, No.4: 133 150

Shleifer Andrei and Robert W. Vishny (1998b). The Grabbing- Government Pathologies and their Cures. Cambridge, MA: Harvard University Press.

Shleifer Andrei (2004). Does Competition Destroy Ethical Behavior? American Economic Review, Vol. 94, No. 2: 414-418.

Sokoloff Kenneth and S. Engerman (2000). Institutions, Factor Endowments, and the Path of Development, Journal of Economic Perspectives, Vol.14, No. 3: 217-232.

Stasavage (2005). Democracy and Education Spending in Africa, American Journal of Political Science, Vol. 49 No 2: 343-358.

Svejnar Jan (2002) Transition Economies: Performance and Challenges, Journal of Economic Perspectives, Vol. 16, No. 1: 3-28

Stiglitz Joseph ( 2003)Ethics, Market and Government Failure and Globalization, The Governance of Globalization, The Proceedings of the Ninth Plenary Session of the Pontifical Academy of Social Sciences, Acta 9, Edmund Malinvaud and Louis Sabourin, eds. Casina Pio iv, 2-6, May 2003.

Tanzi Vito (1998). Corruption Around the World: Causes, Consequences, Scope and Cures, IMF Staff Papers, Vol. 45, No 4: 559-594.

Tullock Gordon (1967) The Welfare Costs of Tariffs, Monopolies and Theft, Western Economic Journal, 5, 22432.

Wei Shang-Jin (1997) Gradualism versus Big Bang: Speed and Sustainability of Reforms, Canadian Journal of Economics, Vol. 30, No. 4: 1234-247.

Woo W.T (1993) The Art of Reforming Centrally-Planned Economies: Comparing China, Poland and Russia. Paper presented at the Conference on the Tradition of Centrally Planned Economies in Pacific Asia. San Francisco: Asia Foundation in San Francisco, 7-8 May.

Wantchekon Leonard, Tamar Asadurian and Emmanuel Nnadozie(2006) Transfer Dependence and Regional Disparities in Nigerian Federalism, in The Dynamics of Federalism: the Political Economic Reality, T.N Srinivasan and Jessica Wallack, eds, Cambridge University Press.

World Bank (1995) Bureaucrats in Business. London: Oxford University Press.

Zoel Jean-Louis (2004). Is There an African Curse? Weatherhead Center for International Affairs, Paper No.0404 , September. 